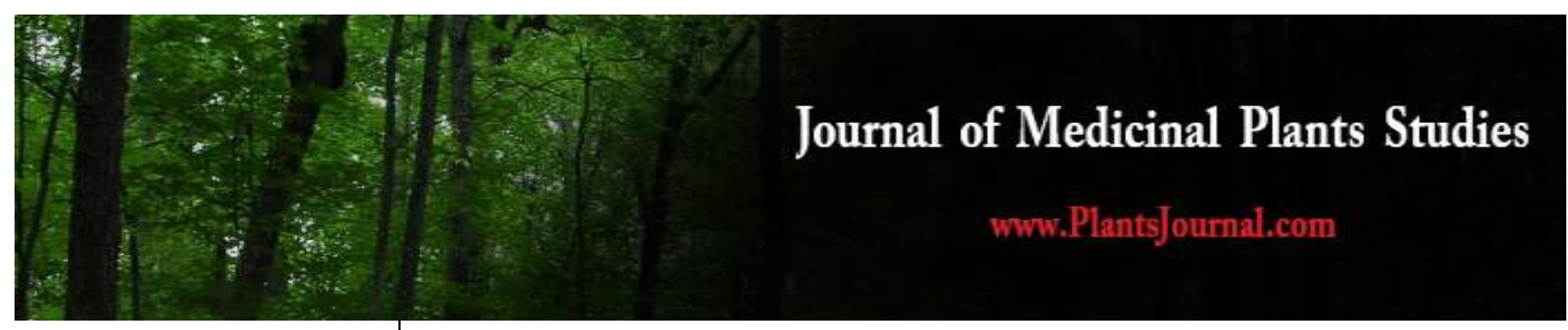

ISSN (E): 2320-3862

ISSN (P): 2394-0530

NAAS Rating: 3.53

www.plantsjournal.com

JMPS 2021; 9(3): 41-51

(C) 2021 JMPS

Received: 08-01-2021

Accepted: 24-03-2021

\section{Harsha Motwani}

Department of Botany,

Bioinformatics and Climate

Change Impacts Management,

Gujarat University, Ahmedabad,

Gujarat, India

\section{Harshida Gadhavi}

Department of Botany,

Bioinformatics and Climate

Change Impacts Management,

Gujarat University, Ahmedabad,

Gujarat, India

\section{Naman Mangukia}

a) Department of Botany,

Bioinformatics and Climate

Change Impacts Management,

Gujarat University, Ahmedabad,

Gujarat, India

b) Bioinnovations, Mumbai,

Maharashtra, India

\section{Saumya K Patel}

Department of Botany,

Bioinformatics and Climate

Change Impacts Management,

Gujarat University, Ahmedabad,

Gujarat, India

\section{Rakesh M Rawal}

Department of Life Science,

School of Sciences, Gujarat

University, Ahmedabad,

Gujarat, India

Hitesh A Solanki

Department of Botany,

Bioinformatics and Climate

Change Impacts Management,

Gujarat University, Ahmedabad,

Gujarat, India

\section{Hepatoprotective plants role in human health: A cross-kingdom review}

\author{
Harsha Motwani, Harshida Gadhavi, Naman Mangukia, Saumya K Patel, \\ Rakesh M Rawal and Hitesh A Solanki
}

DOI: https://doi.org/10.22271/plants.2021.v9.i3a.1292

\section{Abstract}

Liver, being one of the most fundamental and vital organ existing in human body and performing significant role in regulation of enormous number of biological processes including metabolism of biomolecules, secretion, storage, detoxification and excretion of xenobiotics from body. Accomplishment of all these processes leads to acute or chronic hepatic injuries and liver dysfunctions, which sequentially contributes to global health care threat as well as it is a concern for pharmaceutical industry as despite all advancements in medicine there is still a lack of completely assured hepato-protective drugs which stimulate and enhance liver function. However, nature full fills these vacant spaces by providing a number of plant derived hepatoprotective phytochemicals, which are comparatively less toxic and this leads to introduction of an alternative phytotherapeutic approach i.e., the use of poly herbal formulations for treatment of liver diseases. Throughout the world, herbalists claim the use of a number of remedial plants for treatment of hepatic dysfunctions. Nevertheless, recent research also reveals that not only phytochemicals, but also regulatory microRNAs are being transferred from plant to animal kingdom. Thus, this leads to an alternative concept of cross-kingdom gene regulation by non-coding tiny molecules i.e. orally consumed plant derived xeno-MIRs play a chief role in human health regulation. The abilities of microRNAs to regulate cross-kingdom gene regulation have prompted the hopes to explore this novel concept in diagnosis, prognosis and treatment as potential therapeutic and dietary supplements. The present review is aimed to compile the available data of promising hepatoprotective plants and introduce the cross-kingdom gene regulation approach as potential therapy for human health care.

Keywords: Cross-kingdom, hepatoprotective plants, liver dysfunctions, microRNAs, phytochemicals

\section{Introduction}

RNA interference or silencingis a mechanism of sequence specific regulation of gene expression which is prompted by RNA and results in negative regulation of gene expression by non-coding RNAs ${ }^{[1-3]}$. Based on their origin, effector protein association and mode of processing, these small RNAs are further categorised into microRNAs (miRNAs), small interfering RNA (siRNAs), PIWI-interacting RNA (piRNA) and transfer RNA derived small RNA (tsRNAs) ${ }^{[4]}$.

Lin-4 - the first small RNA was identified and reported in early 90's. Later, the regulatory properties of small RNA were illuminated when regulation of lin-14 by lin-4 was reported ${ }^{[2,3]}$. Even after achieving these milestones in RNA world, it took almost a decade to uncover their fundamental role in gene regulation. Today the RNA world is being explored not only for enzymatic properties of RNA but also for regulatory properties. Adding a layer of complexity to many disorders, these small regulatory molecules provide a new horizon of research ${ }^{[5]}$.

Approximately 19-24 mers long, small RNA molecules, having negative regulatory and epigenetic properties, categorised as miRNAs are being identified and reported to be involved almost in every biological process irrespective of plants and animals ${ }^{[6,7]}$. miRNAs are one such class of small RNAs having big effects in gene regulation, originating from non-protein coding genes, majorly located in intronic regions ${ }^{[2]}$.

Recent advancements in High-throughput sequencing such as small-RNA sequencing and Degradome sequencing have paved new ways in direction of miRNA directed gene regulation ${ }^{[8]}$. Over the past decade, hundreds of miRNAs have been reported from different species with the aid from advancements in NGS platforms and ever growing bioinformatics tools. After a decade of rigorous research across the globe, today the crucial regulatory role of miRNAs in multiple metabolic processes, developmental cycles, cell proliferation, cell signalling and cell
Corresponding Author: Hitesh A Solanki

Department of Botany, Bioinformatics and Climate Change Impacts Management, Gujarat University, Ahmedabad, Gujarat, India 
differentiation is well documented for both plant and animal species ${ }^{[3,5,7,9]}$.

Recent studies have exploited presence of these miRNAs in various diseases and disorders ranging from Alzheimer's to diabetes, cancer to neural disorders, liver disorders to anxiety disorders ${ }^{[2,8]}$. Till now, number of plant derived miRNAs is reported to play key role in plant development cycles, stress resistance, host-pathogen interaction, increased yield, etc. miRNA induced gene silencing (MIGS) and artificial microRNAs (amiRNAs) are currently being exploited for agro-research and healthcare research ${ }^{[10,11 \& 12]}$. However, at present scenario health care research is shifting towards Ayurgenomics. The most ancient record for the use of plants to cure diseases in human race is documented in the 'Rigveda' ${ }^{[13]}$. The focus on Ayurvedic research is accelerated worldwide as $80 \%$ of population depends upon the use of traditional medicines, which is pre-dominantly a plant material ${ }^{[14,15,16]}$. Herbalists believe that nature has answers and probably all the cures to treat majority of diseases and this is evident from the key role played by plants in human health care ${ }^{[17,18]}$. Tribal communities are known to use their traditional knowledge of medicinal plants, and use it as drugs to treat multiple diseases or disorders. Since decades, this knowledge of ayurvedic drugs is being passed over generations among the tribal communities $[19,20]$. Recently the use of herbal plants with Hepatoprotective activities are gaining more attention and are preferred over modern medicine due to the fact that natural medicines are harmless i.e. unlike modern medicine these products do not cause hepato-toxicity ${ }^{[16,21,22]}$.

After a lot of research and multiple biochemical assays on plants, some researchers successfully identified active hepatoprotective compounds. Flavonoids are believed to be most important hepato-protective compounds as they help the system by reducing free radicals [16, $21 \& 22]$. The isolated compounds also included apigenin, sylimarin, genistein, quercetin, kaempherol and catechins ${ }^{[22,23]}$. Some studies also revealed that liver-protective plants have phenols, coumarins, monoterpenes, glycosides, alkaloids and xanthenes ${ }^{[16,22]}$.

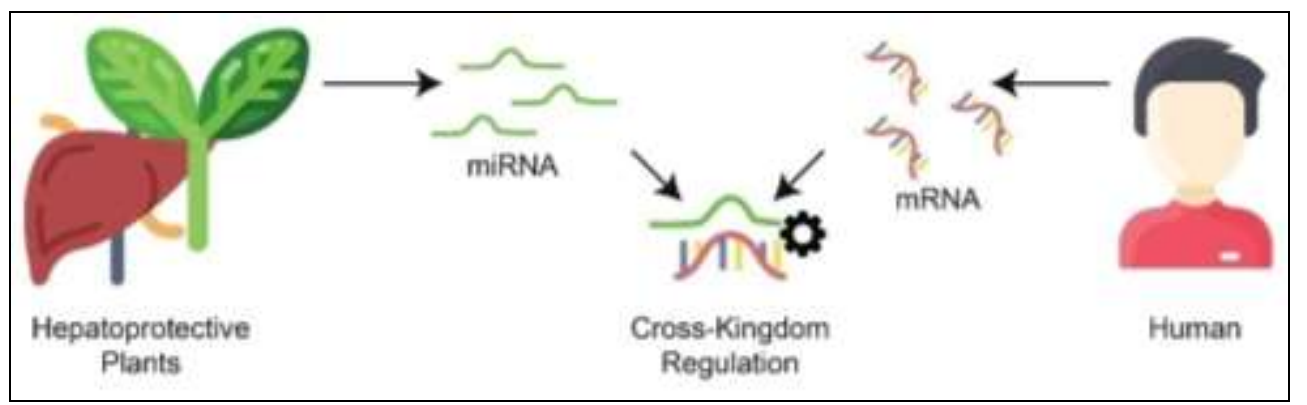

Fig 1: Hepatoprotective plants in cross-talk with Human

Research on Andrographis Paniculata coins andrographolide as the chief liver-protective and anti-liver-toxic constituent ${ }^{[14,}$ $24 \& 25]$. Phyllanthus amarus is reported to show liverprotective effect by lowering down the content of thiobarbituric acid reactive substances (TBARS) ${ }^{[13,26,27]}$. Oral administration of ethanol (EtOH) extract from the leaves of Cnidoscolus chayamansa demonstrated a protective effect against the hepatotoxicity ${ }^{[28]}$.

Hepatoprotective effect generated against the sub-acute liver damage by the aqueous extract of Allium sativum bulbs, attributes this protection to the flavonoids present in the plant extract ${ }^{[23,28]}$. The $95 \%$ ethanol extract, aqueous extract and methanol extract of Asteracantha longifoliaare also reported for hepato-protective activities against $\mathrm{CCl} 4$ and acetaminophen and also accelerate the regeneration of liver cells ${ }^{[28]}$. $70 \%$ acetonic extract from Punica granatum is documented to show hepatoprotective effect against hepatotoxicity ${ }^{[28]}$.

Few more documents report hepato-protective effects of methanol extract of Annona squamosa, ethanol extract from the aerial parts of Acanthospermum hispidum, methanol extract of Helminthostachys zeylanica, leaf extract of Alchornea cordifolia, leaf extract of Ziziphus mauritiana, aqueous extracts of fresh tuber roots of Daucos carota andaqueous extract of the roots of Rhoicissus tridentata against $\mathrm{CCl} 4$ and acetaminophen induced liver damage ${ }^{[22,28]}$. Even though consumable plants are meant for nutrition and food supply, but an emerging concept of communication across the kingdoms has now reached to the level of gene regulation ${ }^{[29,30]}$. A few testimonies favour trans-kingdom gene regulation mediated by plant derived xeno-miRs have aggravated the elation of researchers towards the exploration of these small gene regulators for betterment of human health and therapeutic purposes [31, 32]. Thus cross kingdom gene regulation proves to be a vital key to resolve the regulation communicated by plants on human genes and metabolic pathways.

\section{Hepatoprotective plants}

By mining a huge amount of available literature we have identified number of plants which have promising hepatoprotective activities (Table 1), and this includes Picrorrhiza kurroa, Andrographis paniculata, Eclipta alba, Silibum marianum, Phyllanthus maderaspatensis, Trichopus zeylanicus, Orthosiphon stamineus, Glycyrrhiza glabra Linn, Saururus chinensis, Cordia macleodii, Arachniodes exilis, Amaranthus spinosus, Aerva lanata Linn, Ocimum snctum, Cassia roxburghii, and Indigofera tinctoria ${ }^{[19]}$. The Ayurvedic medicinal system, which has been practiced in Indian Subcontinent by indigenous tribal communities since past 5000 years is based on the mammoth potential of remedial plants which are used orthodoxly and this knowledge is transferred among the generations ${ }^{[19,20,33]}$.

The growing popularity of using number of poly-herbal formulations and extracts in treatment of various diseases ranging from cancer to liver injuries is due to the reason that herbal formulations are not harmful, and are effective with minimum reported side-effects as well as easily extracted from natural resources ${ }^{[27,28]}$. Furthermore, due to scarcity of safe therapeutic choices and unsatisfactory results, medicines have increased usage of alternative herbal therapeutic options $[16,21]$. Even till date, modern pharmaceuticals are reported to contain $25 \%$ constituents derived from herbs ${ }^{[22]}$. In modern day, this approach of using phyto-constituents as drugs is referred as phyto-therapeutic approach. Since time immemorial, indigenous tribal communities have been 
practicing this phyto-therapeutic approach to cure various liver disorders including hepatitis, fatty liver and hepatotoxicity induced by multiple agents ${ }^{[34]}$. Derived from a number of phytochemical analyses of hepato-protective plants, it has been reported that these hepato-protective herbs contain like phenols, coumarins, lignans, essential oil, monoterpenes, carotinoids, glycosides, flavanoids, organic acids, lipids, alkaloids and xanthenes, which are responsible for anti hepat-toxic activities ${ }^{[15]}$.

Some of the renowned herbal medicines being consumed by patients suffering from hepatic disorders, are reported to contain Picrorhiza kurroa, Andrographis paniculata, Terminalia chebula, Phyllanthus niruri, Eugenia Jambolana.

\subsection{Picrorhiza kurroa}

Ayurveda mentions Picrorhiza kurroa (family Scrophulariaceae) as a potent herb that has been widely used as an alternative to treat multiple hepatic disorders. It has also been reported as an imperative element in many herbal preparations for hepatic ailments. Phytochemical studies to evaluate hepatoprotective activities of Picrorhiza kurroa identifies and lists picroliv (mixture of picroside $\mathrm{I}$ and kutkoside ) as the active phytoconstituent, isolated from roots and rhizomes, used as anti hepato-toxic agent in liver diseases such as jaundice. A study concludes picroliv as hepatoprotective constituent against ethanol-induced hepatic injury. These conclusions are drawn from the studies in which $P$. kurroa extract successfully reduced the activities of SOD and CAT. This study also confirms the dose dependent protective activity of $P$. kurroa against ethanol-induced hepatic injury. In a study, animals treated with picroliv showed reduction in levels of AST, ALT and ALP, which were earlier increased due to induced hepatic injury, this helps to conclude the hepatoprotective activity of picroliv ${ }^{[36,37]}$.

\subsection{Terminalia chebula}

Terminalia chebula (family Combetraceae), commonly known as chebulic myrobalan, is reported as a potent herbal drug for multiple disorders in Ayurvedic pharmacopoeia, found in abundance in North India. Phytochemical studies identify and report chebuloside II as the active phytoconstituent involved in biological activities of $T$. chebula. Documents and literature states mature and dried fruit of $T$. chebula has proven to be functionally effective to treat a number of ailments ranging from urinary tract infections to cardiovascular and hepatic ailments. In a study T. chebula fruit ethanolic extract was assessed and evaluated against induced hepato toxicity by administration of rifampicin (RIF), isoniazid (INH) and pyrazinamide (PZA) and this study reported the result that $T$. chebula extract was found to be effectively preventing the induced hepato toxicity by notably attenuated the elevated levels of serum AST, ALT, and LDH level in toxicated animals ${ }^{[38,39]}$.

\subsection{Andrographis paniculata}

Andrographis paniculata (family Acanthaceae), also known as "king of bitters", is described as Kalmegha in Ayurveda medicine system. This herbaceous plant is mentioned in a number of literatures for its biological properties such as hepato-protective and anti-inflammatory abilities. Literature mining reveals a number of studies which postulate Andrographolide as a major hepato protective phytoconstituent present in this remedial herb, which protects the hepatocytes due to its free radicle scavenging property.
Phytochemical studies report Andrographolide as the major active constituent responsible for biological activities such as anti-inflammatory, anti-allergic and hepato-protective. It is also documented that ethanol and aqueous extract of $A$. paniculata was found to be effective in decreasing blood glucose levels in experimental animals, which signifies its anti-diabetic activity. Experimental studies also conclude that levels of Serum enzymes such as ALT, SGPT and SGOT were found to be decreased but increased levels of proteins were reported after the administration of ethanolic extract of A. paniculata. A Histology study conducted on liver sections of experimental animals revealed that treatment of animals with extract of $A$. paniculata resulted in hepatocyte regeneration and leading it to normal histology. Thus it helps to conclude the hepato-protective role of Andrographis paniculata against induced liver toxicities ${ }^{[40,41]}$.

\subsection{Phyllanthus niruri}

Phyllanthus niruri (family Euphorbiaceae), a perennial herb distributed throughout India, is reported to be used to treat various infirmities, predominantly hepatitis. A study done by Shamasundar et al., 1985, revealed the chief phytoconstituents present in $P$. niruri extract such as phyllanthin and hypophyllanthin are responsible for imparting its remedial activity which includes protection against liver toxicity. Experimental study done to evaluate the potential of $P$. niruri extract against ccl4 induced hepato-toxicity in experimental animals revealed that the changes caused by ccl4 were significantly reversed by the test extract i.e. the elevated levels of serum enzymes GOT and GPT were attenuated back to normal levels, this symbolises the anti hepato-toxic effect of $P$. niruri extract. In vitro studies conducted on aqueous extract of the plant reveals its potential as a promising hepato protective agent, as it was found as a vigorous inhibitor of lipid peroxidation and also demonstrated anti-oxidant activity. A study concluded that administration of $P$. niruri aqueous extract in paracetamol intoxicated experimental animals causes a significant reduction in levels of GPT and GOT serum enzymes, which proves it as a hepatoprotective agent against paracetamol ${ }^{[42,43]}$.

\subsection{Eugenia Jambolana}

Eugenia jambolana also known as Syzynium jambolana, (family Myrtaceae), is a large evergreen tree, widely distributed throughout India. Commonly referred as Black plum, is a berry fruit, and is widely used in traditional medicine system such as Ayurveda. Both jamun fruit and seeds are evidenced to retain antioxidant activities due to the presence of alkaloids, flavonoids, glycosides, phytosterols, saponins, tannins and triterpenoids in seeds and existence of raffinose, glucose, fructose, citric acid, anthocyanins, mallic acid and gallic acid in fruit extracts as demonstrated by various phytochemical studies. In experimental studies conducted to estimate hepatoprotective effect of Eugenia jambolana, animals treated with the test extract displayed reduced levels of enzymes (ALT, AST, alkaline phosphatase and total bilirubin) and increased level of total protein and albumin, these results were comparable to standard hepato protective drug Silymarin. Thus it establishes the hepato protective effect of $E$. jambolana against induces toxicity. In a study jambolana fruit extract treatment also resulted in reduced severity of hepatocellular injury and fibrosis which is indicative of the fact that it contains the remedial compounds with hepatoprotective activity ${ }^{[44,45]}$. 
Table 1: Medicinal plants having hepatoprotective potential

\begin{tabular}{|c|c|c|c|c|c|}
\hline Plant & Plant part & Plant Extract & $\begin{array}{c}\begin{array}{c}\text { Hepatic toxicity inducing } \\
\text { agents }\end{array} \\
\end{array}$ & Result & References \\
\hline Curcuma longa & Rhizomes & Ethanol & $\begin{array}{l}\text { Paracetamol, Diethyl } \\
\text { nitrosamine, CCL4 }\end{array}$ & $\begin{array}{l}\text { Reduced serum levels of ALT, AST and } \\
\text { ALP }\end{array}$ & 46 \\
\hline $\begin{array}{l}\text { Trigonella foenum- } \\
\text { graecum }\end{array}$ & Leaves & Ethanol & $\mathrm{H}_{2} \mathrm{O}_{2}, \mathrm{CCL} 4$ & $\begin{array}{l}\text { Reduced serum levels of ALT, AST and } \\
\text { ALP }\end{array}$ & 47 \\
\hline Allium sativum & Raw bulblets & Ethanol & Thioacetamide & Reduced AST, ALP, ALT & 48 \\
\hline $\begin{array}{l}\text { Petroselinum } \\
\text { crispum }\end{array}$ & Leaves & Ethanolic extract & CCL4 & Reduced GOT, GPT, ALP & 49 \\
\hline Mentha piperita & Leaves & $\begin{array}{c}\text { Extraction of essential } \\
\text { oil, Ethanol extract }\end{array}$ & CCL4 & $\begin{array}{c}\text { Decreased the elevated levels of ALT, } \\
\text { AST, ALP, LDH }\end{array}$ & 50,51 \\
\hline Olea europaea & Leaf & $\begin{array}{c}\text { Methanol } \\
\text { Aqueous }\end{array}$ & CCL4, Paracetamol & $\begin{array}{c}\text { Decrease or normalised AST, ALT, ALP } \\
\text { and LDHlevels }\end{array}$ & 52,53 \\
\hline $\begin{array}{c}\text { Agrimonia } \\
\text { eupatoria }\end{array}$ & Aerial parts & Water extract & Ethanol-induced & Decrease in AST, ALT, ALP levels & 54,55 \\
\hline Alhagi maurorum & Whole plant & Ethanol & Paracetamol & $\begin{array}{l}\text { Reduced SGPT, SGOT, ALP and Total } \\
\text { Bilirubin level }\end{array}$ & $\begin{array}{l}56, \\
57\end{array}$ \\
\hline Arctium lappa & Root & Aqueous & $\begin{array}{l}\text { CCL4, Acetaminophen, } \\
\text { Ethanol }\end{array}$ & $\begin{array}{c}\text { SGOT, triglyceride levels and SGPT } \\
\text { elevations were reduced }\end{array}$ & 58,59 \\
\hline Brassica nigra & Leaves & Methanol & D-galn intoxicated rats & $\begin{array}{l}\text { Decreased activities of SGOT, SGPT, } \\
\text { LDH. Total protein and albumin were } \\
\text { significantly Increased }\end{array}$ & 60 \\
\hline Caesalpinia crista & $\begin{array}{l}\text { Leaves } \\
\text { Seeds }\end{array}$ & $\begin{array}{l}\text { Methanol } \\
\text { Ethanol }\end{array}$ & $\begin{array}{c}\text { Iron-overload induced liver } \\
\text { injury. CCL4 \& Paracetamol }\end{array} \mid$ & $\begin{array}{c}\text { Reduced the elevated levels of serum } \\
\text { enzymes - ALT, AST, ALP, and bilirubin }\end{array}$ & 61,62 \\
\hline Calotropis procera & Flowers & Hydro-ethanolic extract & $\begin{array}{c}\text { Paracetamol-induced } \\
\text { hepatitis }\end{array}$ & $\begin{array}{l}\text { Reduced the elevated levels of SGPT, } \\
\text { SGOT, ALP, bilirubin, cholesterol. }\end{array}$ & 63 \\
\hline Cassia occidentalis & Root & Aqueous & CCL4 & ALT, AST and GGT decreased & 64 \\
\hline $\begin{array}{c}\text { Coriandrum } \\
\text { sativum }\end{array}$ & $\begin{array}{c}\text { Leaves and } \\
\text { stem }\end{array}$ & Ethanol & CCL4 & $\begin{array}{c}\text { Decreased ALT, AST, ALP and total } \\
\text { bilirubin }\end{array}$ & 65 \\
\hline Crocus sativus & $\begin{array}{l}\text { Petals } \\
\text { And dried } \\
\text { red stigmas }\end{array}$ & $\begin{array}{c}\text { Hydroalcoholic extract, } \\
\text { Aqueous and } \\
\text { Ethanolic extract } \\
\end{array}$ & $\begin{array}{l}\text { Acetaminophen and } \\
\text { Amiodarone-induced }\end{array}$ & $\begin{array}{l}\text { Nearly normal levels of ALT, AST, total } \\
\text { bilirubin, total proteins and albumin. } \\
\text { Decreased serumALT, AST and LDH }\end{array}$ & 66,67 \\
\hline Crotalaria juncea & Seed & Petroleum ether extract & $\begin{array}{l}\text { Thioacetamide induced } \\
\text { acute hepatic damage }\end{array}$ & $\begin{array}{c}\text { Extremely significant Reduction of } \\
\text { elevated values such as AST, ALT, ALP } \\
\text { and bilirubin }\end{array}$ & 68 \\
\hline Cuminumcyminum & Seeds & Crude extract & Cisplatin CCL4 & $\begin{array}{c}\text { Decreased the level of ALT, AST, and ALP } \\
\text { along with increasing the level of total } \\
\text { protein content }\end{array}$ & 69,70 \\
\hline Cynodondactylon & Leaves & $\begin{array}{l}\text { Phosphate buffered } \\
\text { saline }\end{array}$ & CCL4 & $\begin{array}{c}\text { The activity of SGOT and SGPT was found } \\
\text { to be significantly decreased }\end{array}$ & 71 \\
\hline $\begin{array}{l}\text { Cyperus } \\
\text { alternifolius }\end{array}$ & Aerial parts & Ethanol & CCL4 & AST, ALT and ALP decrease & 72 \\
\hline Daucus carota & Roots & Aqueous & $\begin{array}{c}\text { Paracetamol, isoniazid and } \\
\text { alcohol }\end{array}$ & $\begin{array}{c}\text { Restored the elevated enzyme ALT \& AST } \\
\text { levels to normal and significantly reduced } \\
\text { bilirubin }\end{array}$ & 73 \\
\hline $\begin{array}{l}\text { Eupatorium } \\
\text { cannabinum }\end{array}$ & $\begin{array}{c}\text { (Stems, } \\
\text { flowers, and } \\
\text { leaves })\end{array}$ & Aqueous & CCL4 & $\begin{array}{c}\text { Glutamic pyruvic transaminase } \\
\text { Cannabinum showed a significant decrease } \\
\text { of GPT levels }\end{array}$ & 74 \\
\hline Foeniculum vulgare & Seeds & Hydroalcoholic extract & Paracetamol & ALP, ALT and AST decreased & 75 \\
\hline Galium verum & Aerial parts & Dry extracts & CCL4 & $\begin{array}{c}\text { Decrease in serum ALT and AST activity } \\
\text { and ALP activity and an increase in serum } \\
\text { cholinesterase activity }\end{array}$ & 76 \\
\hline Glycyrrhiza glabra & Root & Powdered & CCL4 & $\begin{array}{l}\text { Significant decrease in the activities of } \\
\text { LDH, gpt and GOT }\end{array}$ & 77 \\
\hline Helianthus annuus & $\begin{array}{c}\text { Seeds } \\
\text { Leaves }\end{array}$ & $\begin{array}{c}\text { Methanolic and } \\
\text { Hydromethanol extract }\end{array}$ & $\begin{array}{c}\text { Paracetamol } \\
\text { Acetaminophen }\end{array}$ & Decrease in ALT, AST and ASP & 78,79 \\
\hline $\begin{array}{c}\text { Hibiscus } \\
\text { cannabinus }\end{array}$ & Leaves & Aqueous & CCL4 \& Paracetamol & Decrease in ALT, AST and billirubin & 80 \\
\hline $\begin{array}{l}\text { Hibiscus rosa- } \\
\text { sinensis }\end{array}$ & $\begin{array}{c}\text { Flowers and } \\
\text { Aerial parts }\end{array}$ & $\begin{array}{l}\text { Aqueous } \\
\text { And } \\
\text { Ethanol } \\
\end{array}$ & $\begin{array}{c}\text { Hypercholesterolemia } \\
\text { induced by feeding pure } \\
\text { cholesterol and cholic acid } \\
\end{array}$ & $\begin{array}{c}\text { Decreased the levels of AST, ALT, ALP } \\
\text { enzymes }\end{array}$ & 81,82 \\
\hline Juglans regia & Leaves & Ethanol & CCL4 & $\begin{array}{c}\text { Serum ALT, AST, ALP and albumin levels } \\
\text { decreased }\end{array}$ & 83 \\
\hline Boerhaavia diffusa & $\begin{array}{l}\text { Roots and } \\
\text { Leaves }\end{array}$ & Ethanol & $\begin{array}{l}\text { Country made liquor and } \\
\text { acetaminophe }\end{array}$ & $\begin{array}{c}\text { Significant fall in serum ALT, triglycerides } \\
\text { cholesterol and lipids and tissue } \\
\text { triglycerides and cholesterol. } \\
\text { Decreases in the values of serum AST, } \\
\text { ALT, ALP, bilirubin and LDH } \\
\end{array}$ & 84,85 \\
\hline
\end{tabular}




\begin{tabular}{|c|c|c|c|c|c|}
\hline Eclipta alba & Leaves & $\begin{array}{l}\text { Ethanolic } \\
\text { Aqueous }\end{array}$ & Alcohol, Paracetamol, CCL4 & $\begin{array}{c}\text { Restored paracetamol induced elevated } \\
4 \text { serum level of ALT, AST and ALP towards } \\
\text { normal value }\end{array}$ & 86,87 \\
\hline Picrorhiza kurroa & $\begin{array}{c}\text { Dried } \\
\text { rhizomes }\end{array}$ & Aqueous & Alcohol cytotoxicity & LDH, got and gpt decreased & 88 \\
\hline Tephrosia purpurea & Aerial parts & Hydro-alcoholic extract & Sodium arsenite & $\begin{array}{c}\text { Decreased elevated levels of ALT, AST, } \\
\text { ALP }\end{array}$ & 89 \\
\hline Phyllanthus amarus & Aerial par & Aqueous extract & Ethanol & Decreased ALT, AST back to normal & 90 \\
\hline Mimosa pudica & Leaves & Methanol & $\mathrm{CCL} 4$ & $\begin{array}{c}\text { Decrease in the elevated levels of SGPT, } \\
\text { SGOT, ALP, TBL }\end{array}$ & 91 \\
\hline Adhatoda vasica & Leaf & Aqueous & $\begin{array}{c}\text { D-galactosamine-induced } \\
\text { liver damage }\end{array}$ & $\begin{array}{c}\text { Decreased SGOT,SGPT and TBARS levels } \\
\text { back to normal }\end{array}$ & 92 \\
\hline Aerva lanata & $\begin{array}{l}\text { Leaves and } \\
\text { Whole plant }\end{array}$ & Ethanol & $\begin{array}{l}\text { Paracetamol } \\
\text { And CCL4 }\end{array}$ & $\begin{array}{c}\text { Decreased levels of SGOT, SGPT, ALP, } \\
\text { LDH }\end{array}$ & 93,94 \\
\hline Morus alba & Leaves & $\begin{array}{l}\text { Alcoholic extract and } \\
\text { Water extract }\end{array}$ & CCL4 & $\begin{array}{c}\text { Decreased SGOT, SGPT, ALP and serum } \\
\text { bilirubin }\end{array}$ & 95 \\
\hline Rosa damascena & $\begin{array}{c}\text { Fresh petals } \\
\text { and } \\
\text { Flowering top }\end{array}$ & $\begin{array}{l}\text { Acetone fraction and } \\
\text { ethanol }\end{array}$ & $\begin{array}{l}\text { CCL4 and } \\
\text { Paracetamol }\end{array}$ & $\begin{array}{c}\text { Serum ALP, GPT and got activity reduced. } \\
\text { AST, ALT and ALP were found to be } \\
\text { elevated after the administration of } \\
\text { paracetamol, which was significantly } \\
\text { reversed by extract }\end{array}$ & 96,97 \\
\hline Nymphaea alba & Flowers & Ethanol & Isoniazid & Significant decrease in AST, ALT, ALP & 98 \\
\hline Silybum marianum & Seeds & Ethanol & Thioacetamide & $\begin{array}{l}\text { Reduced the level of enzymes activity } \\
\text { SGPT, SGOT and ALP and the level of } \\
\text { total bilirubin, }\end{array}$ & 99 \\
\hline Flacourtia indica & $\begin{array}{l}\text { Leaves and } \\
\text { Aerial parts }\end{array}$ & $\begin{array}{c}\text { Aqueous extract and } \\
\begin{array}{c}\text { Petroleum ether ethyl } \\
\text { acetate }\end{array}\end{array}$ & $\begin{array}{l}\text { CCL4 and } \\
\text { Paracetamol }\end{array}$ & $\begin{array}{c}\text { Significant decrease in ALP, AST, ALT } \\
\text { and TBARS \& significant increase in level } \\
\text { of Total protein }\end{array}$ & 100,101 \\
\hline Annona squamosal & Dried seeds & Ethanol & Alcohol & $\begin{array}{l}\text { Significantly decreased the levels of } \\
\text { elevated ALT, AST, ALP, LDH, SBL and } \\
\text { CHL while significantly increased the } \\
\text { reduced levels of total protein and albumin }\end{array}$ & 102 \\
\hline Chamomile capitula & $\begin{array}{c}\text { Dry } \\
\text { Chamomile } \\
\text { flowers }\end{array}$ & $\begin{array}{l}\text { Aqueous extract and } \\
\text { Aqueous Ethanolic } \\
\text { extract }\end{array}$ & \begin{tabular}{|c|} 
2,4-Dichlorophenoxyacetic \\
Acid and \\
Paracetamol \\
\end{tabular} & $\begin{array}{c}\text { Reduced the elevated serum levels of ALT } \\
\text { and AST, ALP and bilirubin and } \\
\text { Decrease in LDH }\end{array}$ & 103,104 \\
\hline Coccinia grandis & Leaves & $\begin{array}{l}\text { Ethanolic } \\
\text { Aqueous }\end{array}$ & CCL4 & $\begin{array}{c}\text { Significant decrease in levels of SGOT, } \\
\text { SGPT, ALKP. }\end{array}$ & 105 \\
\hline Aegle marmelos & Leaves & Ethanolic extract & Alcohol and CCL4 & $\begin{array}{c}\text { Lower levels of SGOT, SGPT, ALP and } \\
\text { bilirubin }\end{array}$ & 106,107 \\
\hline Cassia roxburghii & Seeds & Methanolic extract & $\begin{array}{l}\text { Ethanol and } \\
\text { CCL4 }\end{array}$ & $\begin{array}{l}\text { Decrease in SGOT, SGPT and ALP along } \\
\text { with a significant increase in tp, albumin. }\end{array}$ & 108 \\
\hline Ficus carica & Leaves & Methanol extract & CCL4 & Lower values of ALP, ALT, AST & 109 \\
\hline Lepidium sativum & Seeds & Ethanolic extract & $\begin{array}{l}\text { D-galactosamine and } \\
\text { lipopolysaccharide }\end{array}$ & $\begin{array}{l}\text { Reduction in serum AST, ALT, ALP, and } \\
\text { bilirubin level. }\end{array}$ & 110 \\
\hline Solanum nigrum & $\begin{array}{l}\text { Whole plant } \\
\text { and Dried } \\
\text { fruits }\end{array}$ & $\begin{array}{l}\text { Methanolic and } \\
\text { Ethanol }\end{array}$ & CCL4 & $\begin{array}{c}\text { Reduction of the elevated AST, ALT, ALP } \\
\text { and serum bilirubin concentration values }\end{array}$ & 111,112 \\
\hline
\end{tabular}

\section{3. miRNAs}

miRNAs are a class of small epigenetic regulators, approximately 19-24 nucleotides long single stranded RNA molecules, originating from their precursor molecules ${ }^{[113]}$. These evolutionarily conserved single stranded small RNAs originate from non - coding genes, majorly located in intergenic regions and few occurring in intronic regions ${ }^{[14]}$. Though, these miRNAs originate from non-coding genes but manipulate the regulation of protein coding transcripts i.e. mRNAs which originate from coding regions, by predominant target cleavage or translation inhibition, thus mediating gene silencing at post-transcriptional stage hence sometimes these miRNAs are also referred as post-transcription regulators ${ }^{[115]}$. The production of mature miRNA is a complex multi-step procedure involving nuclear process, transportation, cytoplasmic processing and Argonaute loading. However, the biogenesis procedure varies in animals and plants. Nevertheless, in both the cases, miRNAs are processed from single stranded primary miRNA transcripts called primiRNAs. In animal nucleus, pri-miRNAs are processed and cleaved by the activity of multifaceted microprocessor which contains Drosha - RNaseIII enzyme and its co-factor DiGeorge syndrome critical region gene 8 protein - DGCR8, which is also a dsRNA-binding protein, this activity results in transformation of pri-miRNAs into shorter hairpin RNAs of approx $65-100 \mathrm{nt}$ pre-miRNAs ${ }^{[113,115]}$. The generated premiRNAs are actively transported by exportin 5 to cytoplasm for further processing which involves cleavage activity of Dicer - RNaseIII enzyme and removal of terminal loop resulting in generation of 22-nt miRNA/miRNA* duplex ${ }^{[116]}$. Subsequently, unwinding of this miRNA/miRNA* duplex by helicase and degradation of one of the strands results in a mature miRNA also known as the guide strand ${ }^{[117]}$.

Conversely, in plants the entire two-step mechanism of generating a mature miRNA occurs only in nucleus by DCL1 - Dicer-like 1 enzyme with the help of hyponastic leaves 1 (hyl1)- a dsRNA binding protein and serrate (se) ${ }^{[116,118]}$. The generated $21 \mathrm{nt}$ mature miRNAs are then incorporated into an Argonaute (AGO1) protein, a central and functional unit of miRNA-induced silencing complex (miRISC) - a complex of proteins that target mRNAs based on sequence complementarity ${ }^{[116-118]}$. Mature miRNA guides the AGO1 to 
identify target mRNAs on the basis of base complementarity and the mechanism for silencing of target mRNA is dependent on the same i.e. perfect complementarity between miRNA-target mRNA results in degradation or cleavage of target mRNA, whereas if the perfect complementarity is lacking among miRNA-mRNA does not results in cleavage but rather it causes translational repression of target mRNA by decapping or exonucleolytic digestion ${ }^{[115,119,120]}$.

\section{4. cross-kingdom regulation}

In past widespread research has been conducted to enlighten the possible paths by which consumable plants impart their regulatory effects on human health and all these studies are found to suspect the possibility of transferring regulatory miRNAs from plant to animal kingdom ${ }^{[121]}$. Cross kingdom analysis of plant miRNAs with human genes provides strong evidence for the stable presence of xeno-miRs in human system as well as their potential regulatory effect involved in multiple biological systems ${ }^{[122]}$.

One of the most revolutionary discoveries was marked by researchers at Monsanto Company in 2009 when they found that plentiful endogenous plant miRNAs displayed perfect complementarity to mammalian genes ${ }^{[123]}$. These findings initiated a wave of research in understanding that exogenous miRNAs can be transferred across species and their role in host species, thus paving a way for cross-kingdom Ayurgenomics $[124,125,126]$. Although the concept of crosskingdom communication through miRNAs was controversial, but for the very first time in 2011 a study by Zhang's team, confirmed that plant derived miR168a can be absorbed intact from mammalian GI tract and remained stable in human system. From there on it entered circulatory system, after accumulation in liver it binds and targets exon 4 of lowdensity lipoprotein receptor adapter protein 1 (LDLRAP1) mRNA and regulates its expression [123, 124]. Thus it was evident from this study that exogenous plant miRs can mimic mammalian indigenous miRs and regulate gene expression [123]. This conclusion also revealed that plant miRNAs target not only endogenous genes, but also exogenous genes by crossing the species barrier ${ }^{[123]}$. Confirmed by another study by Andrew et al. that plant miR159 can be absorbed from sources into human sera and further revealed that mimic of the same can inhibit cell proliferation and it also supressed the xenograft breast tumor growth, if administered orally and this became the first evidence for regulation of cancer genes by plant-derived xeno-MIRs ${ }^{[127]}$.

More recent researches helped to identify and report putative miRNAs from Curcuma longa which bind with various target genes related to human diseases such as diabetes mellitus type II, cardiovascular disorders, Alzheimer's, cancer, and thalassemia ${ }^{[128]}$. Anothercross-kingdom regulation evidence by MIR2911 from honeysuckle plant was reported to inhibit viral replication ${ }^{[126,127]}$. Naked miRNAs cannot survive harsh conditions of gut, to answer this issue further researchers explained miRNA uptake mechanisms by micro vesicles (MV), shedding vesicles (SV), exosomal vesicles (EV), exosomes and apoptotic bodies, packaging of miRNAs in these vesicles protect it against the activities of RNases as well as natural constituents present in herbal diet also contribute to stability of these miRNAs ${ }^{[125,129]}$. In MVs not only miRNAs are packed but along with it RNA induced silencing complex (RISC) components are also packed which ensures the active status of the packaged miRNAs subsequently reaching the destination through circulatory system i.e., the recipient cells wherein it performs its regulatory activity ${ }^{[126]}$. However, few studies also support the concept of 2'-O-methylated 3' ribose sugar ends of miRNAs being the reason of their stability in mammalian sera, plasma and tissues ${ }^{[127]}$.

Hence, these days miRNAs are regarded as new and effective bio-active constituent present in herbal remedies, which can be further exploited for therapeutic effects which are accelerated by technology upgradation in RNA-based therapies which is supported by miRNA interference or silencing. At present, miRNAs are being explored due to their potential to be next generation drugs ${ }^{[130]}$. Current research on Circulating and cell free miRNAs suggests miRNAs can be used as promising biomarkers for prognosis and diagnosis of various diseases ${ }^{[131]}$. This provides a controversial but potentially revolutionary concept of miRNA mediated gene silencing and cross kingdom regulation between plants and animals for further research.

\section{Conclusion and Outlook}

At present descent amount of literature is available which postulates and favours the concept that various kingdoms could exchange or transfer regulatory molecules such as miRNAs across the kingdom as signals for altering gene expression of other kingdom, this indicates the probability of miRNAs emerging as new and unexplored bioactive component available in herbal medicines. However, this potential use of miRNAs in herbal medicines and targeting disease-associated genes in another kingdom with plant derived Xeno-miRs is at exploratory stage. Evaluation of stability of herbal miRNAs in human system and the form in which these miRNAs survive as well as to what extent absorption of these miRNAs occur is still questionable. Furthermore studies are wanted to unravel the mechanism of intestinal absorption, bioavailability, tissue recognition, role and influence of secondary metabolites available in herbal extract. In this review we have tried to explore hepatoprotective plants and miRNAs along with the concept of cross kingdom gene silencing. The inevitable question that how medicinal plants are reported to regulate human genome could be answered by identifying the mechanism of cross-kingdom regulation by xeno-Mirs and molecular signalling mechanism across the species. Thus this concept not only illuminates the role of plant derived miRNAs in human health, involvement of target genes in various diseases but it also reflects the direction of future studies which might explore miRNA mediated cross - kingdom gene regulation, which could be a promising alternative for prevention and treatment of number of diseases. Future perspectives may include health regulation by herbal miRNAs and in-vitro synthesis of potential therapeutic miRNAs with lower side-effects and discovery of novel target genes. More research in this nascent area will not only help us to understand the role of herbal miRNAs in human health, their importance as food resources, but it will also broaden the way for development of alternative approaches for prevention and treatment of human diseases.

\section{Acknowledgements}

Author Naman Mangukia acknowledges his Prime Minister Fellowship award received from SERB, DST, Govt. of India \& CII.

\section{Conflict of Interest}

Authors declare no conflict of interest. 


\section{Abbreviations}

MIRs: micro RNAs

MIGS: Micro RNA Induced Gene Silencing

AST: ASpartate Transaminase

ALP: ALkaline Phosphatase

ALT: ALanine Transaminase

SGPT: Serum Glutamic Pyruvic Transaminase

SGOT: Serum Glutamic-Oxaloacetic Transminase

GOT: Glutamate-Oxaloacetate Transaminase

D-GALN: D-Galactoseamine

HDL: High Density Lipoprotein

ACP: ACidPhosphatase

TBARS: Thio Barbituric Acid Reactive Substance

SBL: Serine- $\beta$-Lactamase

LDH: Lactate Dehydrogenase

\section{References}

1. Taft RJ, Pang KC, Mercer TR, Dinger M, Mattick JS. Non-coding RNAs: regulators of disease. The Journal of Pathology: A Journal of the Pathological Society of Great Britain and Ireland. 2010;220(2):126-39.

2. Malan-Müller S, Joanna Hemmings SM, Seedat S. Big effects of small RNAs: A review of MicroRNAs in anxiety. Mol Neurobiol 2013;47(2):726-39.

3. Anushree N, Shivaprasad PV. Regulation of plant miRNA biogenesis. Proc Indian Natl Sci Acad 2018;84(2):439-53.

4. Wang J, Mei J, Ren G. Plant microRNAs: Biogenesis, homeostasis, and degradation. Front Plant Sci 2019;10:112.

5. Treiber $\mathrm{T}$, Treiber N, Meister G. Regulation of microRNA biogenesis and its crosstalk with other cellular pathways. Nat Rev Mol Cell Biol [Internet]. 2019;20(1):5-20.

6. O'Brien J, Hayder H, Zayed Y, Peng C. Overview of microRNA biogenesis, mechanisms of actions, and circulation. Front Endocrinol (Lausanne). 2018;9(AUG):1-12.

7. Millar AA, Waterhouse PM. Plant and animal microRNAs: Similarities and differences. Funct Integr Genomics 2005;5(3):129-35.

8. Wahid F, Shehzad A, Khan T, Kim YY. MicroRNAs: Synthesis, mechanism, function, and recent clinical trials. Biochim Biophys Acta - Mol Cell Res [Internet] 2010;1803(11):1231-43.

9. Wen-wen K, Hong-bo W, Jing L. Biogenesis of Plant MicroRNAs. J Northeast Agric Univ (English Ed [Internet] 2014;21(1):84-96.

10. Bahadur B, Rajam MV, Sahijram L, Krishnamurthy KV. Plant biology and biotechnology: Plant genomics and biotechnology. Plant Biol Biotechnol Plant Genomics Biotechnol 2015;II:1-768.

11. Li J, Hull JJ, Liang S, Wang Q, Chen L, Zhang Q, et al. Genome-wide analysis of cotton miRNAs during whitefly infestation offers new insights into plantherbivore interaction. Int J Mol Sci 2019;20(21):1-21.

12. Si J, Zhou T, Bo W, Xu F, Wu R. Genome-wide analysis of salt-responsive and novel microRNAs in Populus euphratica by deep sequencing. BMC Genet. 2014;15(1):1-11.

13. Mohamed Saleem TS, Madhusudhana Chetty S, Ramkanth S, Rajan VST, Mahesh Kumar K, Gauthaman K. Hepatoprotective herbs - A review. Int J Res Pharm Sci 2010;1(1):1-5.

14. Sanower Hossain M, Urbi Z, Sule A, Hafizur Rahman
KM. A Review of Ethnobotany, Phytochemistry, and Pharmacology. Sci World J 2014;2014:1-28.

15. Qadir MI, Ahmad Z. Bangladesh Journal of Pharmacology Mini Review Advances in hepatoprotective medicinal plants research. Bangladesh J Pharmacol 2017.

16. Ali SA, Sharief NH, Mohamed YS. Hepatoprotective Activity of Some Medicinal Plants in Sudan. Evidencebased Complement Altern Med 2019.

17. Bello OA, Ayanda OI, Aworunse OS, Olukanmi BI. Pharmacognosy Reviews 2018;1(2):8-15.

18. Jannu V, Baddam PG, Boorgula AK, Jambula SR. A review on hepatoprotective plants. Int J Drug Dev Res 2012;4(3):1-8.

19. Kumar H, Ramesh A, Suresh Kumar JN, Mohammed Ishaq B, Kumar CH. a Review on Hepatoprotective Activity of Medicinal Plants 2011;2(3):501-15.

20. Mahesh AR, Kumar H, Mk R, Devkar RA. Detail Study on Boerhaavia Diffusa Plant for its Medicinal Importance-A Review. Res J Pharm Sci [Internet] 2012;1(1):28-36.

21. Al-Sayed E, Martiskainen O, Seif El-Din SH, Sabra ANA, Hammam OA, El-Lakkany NM, et al. Hepatoprotective and antioxidant effect of bauhinia hookeri extract against carbon tetrachloride-induced hepatotoxicity in mice and characterization of its bioactive compounds by HPLC-PDA-ESI-MS/MS. Biomed Res Int 2014.

22. Adewusi EA, Afolayan AJ. A review of natural products with hepatoprotective activity. J Med Plants Res. 2010;4(13):1318-34.

23. Majee C, Mazumder R, Choudhary AN. Medicinal plants with anti-ulcer and hepatoprotective activity: A review. Int. J Pharm. Sci. Res 2019;1:1-1.

24. Jayakumar T, Hsieh CY, Lee JJ, Sheu JR. Experimental and clinical pharmacology of andrographis paniculata and its major bioactive phytoconstituent andrographolide. Evidence-based Complement Altern Med 2013.

25. Okhuarobo A, Ehizogie Falodun J, Erharuyi O, Imieje V, Falodun A, Langer P. Harnessing the medicinal properties of Andrographis paniculata for diseases and beyond: A review of its phytochemistry and pharmacology. Asian Pacific J Trop Dis 2014;4(3):21322.

26. Shakya AK. Drug-induced hepatotoxicity and hepatoprotective medicinal plants: A review. Indian J Pharm Educ Res 2020;54(2):234-50.

27. Bhawna S, Kumar SU. Hepatoprotective activity of some indigenous plants. Int J Pharm Tech Res 2009;1(4):13304.

28. Jiménez-Arellanes MA, Gutiérrez-Rebolledo GA, Meckes-Fischer M, León-Díaz R. Medical plant extracts and natural compounds with a hepatoprotective effect against damage caused by antitubercular drugs: A review. Asian Pac J Trop Med 2016;9(12):1141-9.

29. Patel M, Gadhvi H, Patel S, Mankad A. Holy basil : Holy herb to multimodal medicine for human health 2018;7(3):418-23. Available from: http://www.thepharmajournal.com/archives/2018/vol7iss ue3/PartG/7-2-13-691.pdf

30. Patel M, Gadhvi H, Mangukia N, Patel NJS, Mankad A, Pandya $\mathrm{H}$, et al. Computational identification of mi RNA and their predicted target genes from Ocimum tenuiflorum draft genome. Pharma Innov [Internet] 2018;7(4-J):1-11. 
31. Zhao Q, Mao Q, Zhao Z, Dou T, Wang Z, Cui X, et al. Predict plant-derived xenomiRs from plant miRNA sequences using random forest and one-dimensional convolutional neural network models. bioRxiv 2018, 113 .

32. Lukasik A, Zielenkiewicz P. In silico identification of plant miRNAs in mammalian breast milk exosomes - A small step forward? PLoS One 2014;9(6).

33. Nagalekshmi R, Menon A, Chandrasekharan DK, Nair CKK. Hepatoprotective activity of Andrographis Paniculata and Swertia Chirayita. Food Chem Toxicol [Internet] 2011;49(12):3367-73.

34. Madrigal-Santillán E, Madrigal-Bujaidar E, ÁlvarezGonzález I, Sumaya-Martínez MT, Gutiérrez-Salinas J, Bautista M, et al. Review of natural products with hepatoprotective effects. World J Gastroenterol. 2014;20(40):14787-804.

35. Sun W, Leng L, Yin Q, Xu MM, Huang M, Xu Z, et al. The genome of the medicinal plant Andrographis paniculata provides insight into the biosynthesis of the bioactive diterpenoid neoandrographolide. Plant $\mathbf{J}$ 2019;97(5):841-57.

36. Jia D, Barwal I, Thakur S, Yadav SC. Methodology to nanoencapsulate hepatoprotective components from Picrorhiza kurroa as food supplement. Food Biosci [Internet] 2015;9:28-35.

37. Saraswat B, Visen PKS, Patnaik GK, Dhawan BN. Ex vivo and in vivo investigations of picroliv from Picrorhiza kurroa in an alcohol intoxication model in rats. J Ethnopharmacol 1999;66(3):263-9.

38. Tasduq SA, Singh K, Satti NK, Gupta DK, Suri KA, Johri RK. Terminalia chebula (fruit) prevents liver toxicity caused by sub-chronic administration of rifampicin, isoniazid and pyrazinamide in combination. Hum Exp Toxicol 2006;25(3):111-8.

39. Choi MK, Kim HG, Han JM, Lee JS, Lee JS, Chung SH, et al. Hepatoprotective Effect of Terminalia chebula against t-BHP-Induced Acute Liver Injury in C57/BL6 Mice. Evidence-based Complement Altern Med. 2015;2015.

40. Salunkhe AJ, Patil RN. Hepatoprotective Effect of Ethanolic Extract of Andrographis Paniculata Against Thioacetamide Induced 2018;4(549):549-59.

41. Alasyam N, Narapogu V, John P, Ubedulla S, Pokala N. Evaluation of Hepatoprotective Activity of Aqueous Extract of Andrographis paniculata in Wistar Rats. Int $\mathbf{J}$ Pharmacol Clin Sci 2017;5(4):113-7.

42. Harish R, Shivanandappa T. Antioxidant activity and hepatoprotective potential of Phyllanthus niruri. Food Chem 2006;95(2):180-5.

43. Sabir SM, Rocha JBT. Water-extractable phytochemicals from Phyllanthus niruri exhibit distinct in vitro antioxidant and in vivo hepatoprotective activity against paracetamol-induced liver damage in mice. Food Chem 2008;111(4):845-51.

44. DAS S, SARMA G. Study of the hepatoprotective activity of the ethanolic extract of the pulp of Eugenia Jambolona (Jamun) in albino rats. J Clin Diagnostic Res. 2009;3(2):1466-74.

45. Donepudi AC, Aleksunes LM, Driscoll MV, Seeram NP, Slitt AL. The traditional ayurvedic medicine, E ugenia jambolana (J amun fruit), decreases liver inflammation, injury and fibrosis during cholestasis. Liver International. 2012;32(4):560-73.

46. Salama SM, Abdulla MA, AlRashdi AS, Ismail S,
Alkiyumi SS, Golbabapour S. Hepatoprotective effect of ethanolic extract of Curcuma longa on thioacetamide induced liver cirrhosis in rats. BMC Complement Altern Med 2013, 13.

47. Meera R, Devi P, Kameswari B, Madhumitha B, Merlin NJ. Antioxidant and hepatoprotective activities of Ocimum basilicum linn. And Trigonella foenum-graecum linn. Against $\mathrm{H} 2 \mathrm{O} 2$ and $\mathrm{CCl} 4$ induced hepatotoxicity in goat liver. Indian J Exp Biol 2009;47(7):584-90.

48. Chinnala K, Jayagar P, Motta G, Adusumilli R, Elsani M. Evaluation of hepatoprotective activity of Allium sativum ethanolic extract in thioacetamide induced hepatotoxicity in albino Wistar rats. Am J Res Med Sci. 2018;3(1):48.

49. Al-Howiriny TA, Al-Sohaibani MO, El-Tahir KH, Rafatullah S. Preliminary evaluation of the antiinflammatory and anti-hepatotoxic activities of "Parsley" Petroselinum crispum in rats. $J$ Nat Remedies 2003;3(1):54-62.

50. Bellassoued K, Ben Hsouna A, Athmouni K, Van Pelt J, Makni Ayadi F, Rebai T, et al. Protective effects of Mentha piperita $\mathrm{L}$. leaf essential oil against $\mathrm{CCl} 4$ induced hepatic oxidative damage and renal failure in rats. Lipids Health Dis 2018;17(1):1-14.

51. Ahangari JY. Poultry Science Journal Effects of Peppermint (Mentha piperita L.) Alcoholic Extract on Carbon Tetrachloride-induced Hepatotoxicity in Broiler Chickens Under Heat Stress Condition. Online) Poult Sci J [Internet]. 2015;3(1):1-16.

52. Taamalli A, Feriani A, Lozano-Sanchez J, Ghazouani L, El Mufti A, Allagui MS, et al. Potential hepatoprotective activity of super critical carbon dioxide olive leaf extracts against CCl4-induced liver damage. Foods 2020;9(6).

53. Khalil EAM. Evaluation of the hepatoprotective activity of an aqueous extract of olive leaves in male albino rats. Egypt J Hosp Med 2004;15:118-23.

54. Al-snafi AE. Asian Journal of Pharmaceutical Science \& Technology the Pharmacological and Therapeutic Importance of Agrimonia eupatoria: A Review. 2015;5(2):112-7.

55. Yoon SJ, Koh EJ, Kim CS, Zee OP, Kwak JH, Jeong WJ, et al. Agrimonia eupatoria protects against chronic ethanol-induced liver injury in rats. Food Chem Toxicol [Internet] 2012;50(7):2335-41.

56. Rehman JU, Akhtar N, Khan MYS, Ahmad K, Ahmad $\mathrm{M}$, Sultana S, et al. Phytochemical screening and hepatoprotective effect of Alhagi maurorum boiss (leguminosae) against paracetamol-induced hepatotoxicity in Rabbits. Trop J Pharm Res 2015;14(6):1029-34.

57. Rafiqi UN, Gul I, Saifi M, Nasrullah N, Ahmad J, Dash $\mathrm{P}$, et al. Cloning, identification, and In silico analysis of terpene synthases involved in the competing pathway of artemisinin biosynthesis pathway in Artemisia annua L. Pharmacogn Mag 2019;15(62):S38-46.

58. Lin SC, Chung TC, Lin CC, Ueng TH, Lin YH, Lin SY, et al. Hepatoprotective effects of Arctium lappa on carbon tetrachloride- and acetaminophen-induced liver damage. Am J Chin Med. 2000;28(2):163-73.

59. Lin SC, Lin CH, Lin CC, Lin YH, Chen CF, Chen IC, et al. Hepatoprotective effects of Arctium lappa Linne on liver injuries induced by chronic ethanol consumption and potentiated by carbon tetrachloride. J Biomed Sci 2002;9(5):401-9.

60. Rajamurugan R, Suyavaran A, Selvaganabathy N, 
Ramamurthy CH, Reddy GP, Sujatha V, et al. Brassica nigra plays a remedy role in hepatic and renal damage. Pharm Biol 2012;50(12):1488-97.

61. Sarkar R, Hazra B, Mandal N. Hepatoprotective potential of Caesalpinia crista against iron-overload-induced liver toxicity in mice. Evidence-based Complement Altern Med 2012.

62. Nakul G, Prerna C, Maryam N, Mohammed MS, Meetu A. Hepatoprotective effect of Caesalpinia crista Linn. against $\mathrm{CCl}_{4}$ and paracetamol induced hepatotoxicity in albino rats. African J Pharm Pharmacol 2014;8(18):48591.

63. Ramachandra Setty S, Quereshi AA, Viswanath Swamy AHM, Patil T, Prakash T, Prabhu K, et al. Hepatoprotective activity of Calotropis procera flowers against paracetamol-induced hepatic injury in rats. Fitoterapia. 2007;78(7-8):451-4.

64. Usha K, Mary Kasturi G, Hemalatha P. Hepatoprotective effect of Hygrophila spinosa and Cassia occidentalis on carbon tetrachloride induced liver damage in experimental rats. Indian J Clin Biochem 2007;22(2):132-5.

65. Sreelatha S, Padma PR, Umadevi M. Protective effects of Coriandrum sativum extracts on carbon tetrachlorideinduced hepatotoxicity in rats. Food Chem Toxicol [Internet] 2009;47(4):702-8.

66. Omidi A, Riahinia N, Montazer Torbati MB, Behdani MA. Hepatoprotective effect of Crocus sativus (saffron) petals extract against acetaminophen toxicity in male Wistar rats. Avicenna $\mathrm{J}$ phytomedicine [Internet]. 2014;4(5):330-6.

67. Saleem N, Ahmad M, Kamran S, Riaz H, Mehmood Y, Raza S. Hepatoprotective Effect of Crocus sativus on Amiodarone-Induced Liver Toxicity. Br J Pharm Res. 2016;12(4):1-11.

68. Rahila K, Bhatt L, Chakraborty M, Kamath J. Hepatoprotective Activity of Crotalaria juncea Against Thioacetamide Intoxicated Rats. Int Res J Pharm Appl Sci 2013;3(31):98-101.

69. Nahid A, Lamia A, Elsherif AEM, Ahmed ES, Saber AA, Azra B. Comparative Study of Hepatoprotective Effect Produced By Cuminum. Int J Pharm Sci Res. 2018;9(1):293-301.

70. Nishadh A. Evaluation of hepatoprotective activity of Vernonia Cinerea (L.) less and Cuminum cyminum in carbon tetrachloride induced liver damage in rats. Int $\mathbf{J}$ Pharma Bio Sci 2013;4(4).

71. Prabha DC, Annapoorani S. Hepatoprotective effect of cynodon dactylon on $\mathrm{CCl} 4$ induced experimental mice. J Bio-Science 2009;17(1):27-34.

72. Awaad AS, Soliman GA, El-Sayed DF, El-Gindi OD, Alqasoumi SI. Hepatoprotective activity of Cyperus alternifolius on carbon tetrachloride induced hepatotoxicity in rats. Pharm Biol 2012;50(2):155-61.

73. Shoba S, Patil PA, Vivek V. Hepatoprotective activity of Daucus carota L. Aqueous extract against paracetamol, isoniazid and alcohol induced hepatotoxicity in male wistar rats. Pharmacology online. 2008;3:776-87.

74. Lexa A, Fleurentin J, Lehr PR, Mortier F, Pruvost M, Pelt JM. Choleretic and hepatoprotective properties of Eupatorium cannabinum in the rat. Planta Med 1989;55(2):127-32.

75. Nazir T, Shakir L, Zaka-ur-Rahman, Najam K, Choudhary A, Saeed N, et al. Hepatoprotective Activity of Foeniculum vulgare Against Paracetamol Induced
Hepatotoxicity in Rabbit. J Appl Pharm 2020;12(1):1-6.

76. Goryacha OV, Ilyina TV, Kovalyova AM, Koshovyi OM, Krivoruchko OV, Vladimirova M, et al. A hepatoprotective activity of Galium verum L. extracts against carbon tetrachloride-induced injury in rats. Der Pharma Chem 2017;9(7):80-3.

77. Yin G, Cao L, Xu P, Jeney G, Nakao M, Lu C. Hepatoprotective and antioxidant effects of Glycyrrhiza glabra extract against carbon tetrachloride (CCl4)induced hepatocyte damage in common carp (Cyprinus carpio). Fish Physiol Biochem. 2011;37(1):209-16.

78. Amponsaa Brobbey A, Jibira Y, Baba Fuseini K, NiiLamptey R, Adu JK, Fuseini B. Antioxidant and Hepatoprotective properties of Helianthus annuus seed extract against paracetamol-induced liver toxicity. J Phytopharm [Internet] 2020;9(5):361-6.

79. Onoja SO, Udem SC, Anaga AO. Hypoglycemic, antidyslipidemic, hepatoprotective and anti-lipid peroxidation activities of hydromethanol leaf extract of helianthus annuus in alloxan-induced diabetic rats. Trop $\mathbf{J}$ Pharm Res 2018;17(9):1817-24.

80. Agbor GA, Oben JE, Nkegoum B, Takala JP, Ngogang JY. Hepatoprotective activity of Hibiscus cannabinus (Linn.) against carbon tetrachloride and paracetamol induced liver damage in rats. Pak. J. Biol. Sci 2005;8:1397-401.

81. Biswas A, UJ D, Bhat S. The Hepatoprotective Effect of Hibiscus rosa sinensis Flower Extract on Diet -Induced Hypercholesterolemia in Male Albino Wistar Rats. Int J Med Pharm Sci 2014;04(06):215-7.

82. Ghaffar FRA, El-elaimy IA. In vitro, antioxidant and scavenging activities of $H$. rosasinensis. J Appl Pharm Sci 2012;02(01):51-8.

83. Eidi A, Moghadam JZ, Mortazavi P, Rezazadeh S, Olamafar S. Hepatoprotective effects of Juglans regia extract against $\mathrm{CCl} 4$-induced oxidative damage in rats. Pharm Biol 2013;51(5):558-65.

84. Gollahalli SR. Short Communication. Combust Sci Technol 1979;19(5-6):245-50.

85. Olaleye MT, Akinmoladun AC, Ogunboye AA, Akindahunsi AA. Antioxidant activity and hepatoprotective property of leaf extracts of Boerhaavia diffusa Linn against acetaminophen-induced liver damage in rats. Food Chem Toxicol [Internet] 2010;48(8-9):22005.

86. Rama Parmar S, Vashrambhai PH, Kalia K. Hepatoprotective Activity of Some Plants Extract Against Paracetamol Induced Hepatotoxicity in Rats. J Herb Med Toxicol 2010;4(2):101-6.

87. Singh B, Saxena AK, Chandan BK, Agarwal SG, Anand KK. In vivo hepatoprotective activity of active fraction from ethanolic extract of Eclipta alba leaves. Indian $\mathbf{J}$ Physiol Pharmacol 2001;45(4):435-41.

88. Sinha S, Bhat J, Joshi M, Sinkar V, Ghaskadbi S. Hepatoprotective activity of Picrorhiza kurroa Royle Ex. Benth extract against alcohol cytotoxicity in mouse liver slice culture. Int J Green Pharm. 2011;5(3):244-53.

89. Gora RH, Baxla SL, Kerketta P, Patnaik S, Roy BK. Hepatoprotective activity of Tephrosia purpurea against arsenic induced toxicity in rats. Indian $\mathrm{J}$ Pharmacol 2014;46(2):197-200.

90. Pramyothin P, Ngamtin C, Poungshompoo S, Chaichantipyuth C. Hepatoprotective activity of Phyllanthus amarus Schum. et. Thonn. Extract in ethanol treated rats: In vitro and in vivo studies. J 
Ethnopharmacol 2007;114(2):169-73.

91. Vinothapooshan G, Sundar K. Hepatoprotective activity of Adhatoda vasica leaves against Carbon tetrachloride induced toxicity. Pharmacology online. 2010;2:551-8.

92. Bhattacharyya D, Pandit S, Jana U, Sen S, Sur TK. Hepatoprotective activity of Adhatoda vasica aqueous leaf extract on D-galactosamine-induced liver damage in rats. Fitoterapia. 2005;76(2):223-5.

93. Chaitanya D, Challa SR, Reddy A. Hepatoprotective effect of biherbal ethanolic extract against paracetamolinduced hepatic damage in albino rats. J Ayurveda Integr Med 2012;3(4):198-203.

94. Nevin KG, Vijayammal PL. Effect of Aerva lanata against hepatotoxicity of carbon tetrachloride in rats. Environ Toxicol Pharmacol 2005;20(3):471-7.

95. Hogade MG, Patil KS, Wadkar GH, Mathapati SS, Dhumal PB. Hepatoprotective activity of Morus alba (Linn.) leaves extract against carbon tetrachloride induced hepatotoxicity in rats. African J Pharm Pharmacol 2010;4(10):731-4.

96. Achuthan CR, Babu BH, Padikkala J. Antioxidant and hepatoprotective effects of Rosa damascena. Pharm Biol 2003;41(5):357-61.

97. Alam M, Nyeem M, Awal M, Mostofa M, Alam M, Subhan N, et al. Antioxidant and hepatoprotective action of the crude ethanolic extract of the flowering top of Rosa damascena. Orient Pharm Exp Med 2008;8(2):16470.

98. Nasiruddin M, Khan IA, Arif SH. Therapeutic effect of Nymphaea alba Linn. Flowers against isoniazid-induced hepatotoxicity: An experimental study. Asian J Pharm Clin Res 2018;11(5):333-6.

99. Madani H, Talebolhosseini M, Asgary S, Naderi GH. Hepatoprotective activity of Silybum marianum and Cichorium intybus against thioacetamide in rat. Pakistan J Nutr 2008;7(1):172-6.

100.Gnanaprakash K, C MC, Ramkanth S, Alagusundaram M, Vs T, S AP, et al. World Acadermy Sci Eng Technol. 2010;37:1117-21.

101.Nazneen M, Mazid MA, Kundu JK, Bachar SC, Begum F, Datta BK. Protective effects of Flacourtia indica aerial parts extracts against paracetamol-induced hepatotoxiciy in rats. J Taibah Univ Sci [Internet]. 2009;2(1):1-6.

102.Zahid M, Arif M, Rahman MA, Mujahid M. Hepatoprotective and antioxidant activities of Annona squamosa seed extract against alcohol-induced liver injury in Sprague Dawley rats. Drug Chem Toxicol [Internet] 2020;43(6):588-94.

103.Al-Baroudi DA, Arafat R, El-kholy T. Hepatoprotective effect of chamomile capitula extract against 2, 4dichlorophenoxyacetic acid-induced hepatotoxicity in rats. Life Sci J 2014;11:34-40.

104. Misra N, Gupta AK. Hepatoprotective Activity of Aqueous Ethanolic Extract of Chamomile capitula in Paracetamol Intoxicated Albino Rats. Am J Pharmacol Toxicol 2006;1(1):17-20.

105.Sunilson JAJ, Muthappan M, Das A, Suraj R, Varatharajan R, Promwichit P. Hepatoprotective activity of Coccinia grandis leaves against carbon tetrachloride induced hepatic injury in rats. International Journal of Pharmacology 2009;5:222-7.

106. Singanan V, Singanan M, Begum H, Town A, Shoa W, Nadu T. The Hepatoprotective Effect of Bael Leaves (Aegle marmelos) in Alcohol Induced Liver Injury in Albino Rats Vinodhini Singanan 1, Malairajan Singanan
2 and Hazeena Begum 3. Int J 2007;2(2):83-92.

107. Sumitha P, Thirunalasundari T. Hepatoprotective Activity of Aegle marmelos in $\mathrm{CCl} 4$ Induced Toxicity An In vivo Study 2011;3(1):5-9.

108. Arulkumaran KSG, Rajasekaran A, Ramasamy R, Jegadeesan M, Kavimani S, Somasundaram A. Cassia roxburghii seeds protect liver against toxic effects of ethanol and Carbon tetrachloride in rats. Int $\mathrm{J}$ PharmTech Res 2009;1(2):273-6.

109.Sefidgaran M. Ive Ar Ch of Ive 2010;6(2):125-31.

110.Raish M, Ahmad A, Alkharfy KM, Ahamad SR, Mohsin $\mathrm{K}$, Al-Jenoobi FI, et al. Hepatoprotective activity of Lepidium sativum seeds against D-galactosamine/ lipopolysaccharide induced hepatotoxicity in animal model. BMC Complement Altern Med [Internet] 2016;16(1):1-11.

111.Elhag R, Badwi S El, Bakhiet AMG. Hepatoprotective activity of Solanum nigrum extracts on chemically induced liver damage in rats. $\mathrm{J}$ Vet [Internet] 2011;3(4):45-50.

112.Raju K, Anbuganapathi G, Gokulakrishnan V, Rajkapoor B, Jayakar B, Manian S. Effect of dried fruits of Solanum nigrum Linn against $\mathrm{CCl}$ 4-induced hepatic damage in rats. Biol Pharm Bull 2003;26(11):1618-9.

113. Moro B, Chorostecki U, Arikit S, Suarez IP, Hobartner $\mathrm{C}$, Rasia RM, et al. Efficiency and precision of microRNA biogenesis modes in plants. Nucleic Acids Res 2018;46(20):10709-23.

114.Lin SL, Miller JD, Ying SY. Intronic microRNA (miRNA). J Biomed Biotechnol 2006, 1-13.

115. Achkar NP, Cambiagno DA, Manavella PA. miRNA Biogenesis: A Dynamic Pathway. Trends Plant Sci [Internet] 2016;21(12):1034-44.

116. Murchison EP, Hannon GJ. miRNAs on the move: miRNA biogenesis and the RNAi machinery. Curr Opin Cell Biol 2004;16(3):223-9.

117. Koscianska E, Starega-Roslan J, Krzyzosiak WJ. The role of dicer protein partners in the processing of microRNA precursors. PLoS One 2011;6(12).

118. Voinnet O. Origin, Biogenesis, and Activity of Plant MicroRNAs. Cell [Internet] 2009;136(4):669-87.

119.Tétreault N, De Guire V. MiRNAs: Their discovery, biogenesis and mechanism of action. Clin Biochem [Internet] 2013;46(10-11):842-5.

120. Seok H, Ham J, Jang ES, Chi SW. MicroRNA target recognition: Insights from transcriptome-wide noncanonical interactions. Mol Cells 2016;39(5):375-81.

121. Sharma A, Sahu S, Kumari P, Gopi SR, Malhotra R, Biswas S. Genome-wide identification and functional annotation of miRNAs in anti-inflammatory plant and their cross-kingdom regulation in Homo sapiens. J Biomol Struct Dyn 2017;35(7):1389-400.

122. Sala-Cirtog M, Marian C, Anghel A. New insights of medicinal plant therapeutic activity: The miRNA transfer. Biomed Pharmacother [Internet] 2015;74:228-32.

123.Wang W, Liu D, Zhang X, Chen D, Cheng Y, Shen F. Plant microRNAs in cross-kingdom regulation of gene expression. Int J Mol Sci 2018;19(7).

124.Xie W, Weng A, Melzig MF. MicroRNAs as New Bioactive Components in Medicinal Plants. Planta Med 2016;82(13):1153-62.

125.Zhang L, Hou D, Chen X, Li D, Zhu L, Zhang Y, et al. Exogenous plant MIR168a specifically targets mammalian LDLRAP1: Evidence of cross-kingdom regulation by microRNA. Cell Res 2012;22(1):107-26. 
126.Kumar D, Kumar S, Ayachit G, Bhairappanavar SB, Ansari A, Sharma $\mathrm{P}$, et al. Cross-kingdom regulation of putative miRNAs derived from happy tree in cancer pathway: A systems biology approach. Int $\mathbf{J}$ Mol Sci 2017;18(6):1-21.

127.Chin AR, Fong MY, Somlo G, Wu J, Swiderski P, Wu X, et al. Cross-kingdom inhibition of breast cancer growth by plant miR159. Cell Res 2016;26(2):217-28.

128. Rameshwari R, Singhal D, Narang R, Maheshwari A, Prasad T V. In silico Prediction of mirna in Curcuma longa And Their 2013;4(2):253-9.

129. Vaucheret H, Chupeau Y. Ingested plant miRNAs regulate gene expression in animals. Cell Res. 2012;22(1):3-5.

130.Zhang R, Zheng F, Wei S, Zhang S, Li G, Cao P, et al. Evolution of disease defense genes and their regulators in plants. Int J Mol Sci 2019;20(2):1-25.

131.Liu YC, Chen WL, Kung WH, Huang Da H. Plant miRNAs found in human circulating system provide evidences of cross kingdom RNAi. BMC Genomics 2017;18(2):1-6. 